\title{
The influence of e-service quality, trust, brand image on Shopee customer satisfaction and loyalty
}

\author{
Dola Fitritha Raras Handayani ${ }^{{ }^{*}}$, Retno Widowati $\mathbf{P A}^{2}$, Nuryakin ${ }^{3}$ \\ 1,2,3 Magister Manajemen, Universitas Muhammadiyah Yogyakarka \\ *Corresponding author: fitrithararas1603@gmail.com
}

\begin{tabular}{l} 
Article Info \\
\hline Article history: \\
Received : 3 February 2021 \\
Accepted : 8 February 2021 \\
Published : 1 July 2021 \\
\hline
\end{tabular}

JEL Classification Code: M31, M14, L14

\begin{abstract}
Author's email: retno.widowati@umy.ac.id nuryakindr@gmail.com
\end{abstract}

DOI: 10.20885 /isb.vol25.iss2.art3

\begin{abstract}
Purpose: This research's main objective is to determine the relationship among e-service quality, trust, and brand image to customer loyalty. Customer satisfaction was a mediator which focused on Shopee customers in Yogyakarta.
\end{abstract}

Design/methodology/approach: The research respondents consisted of 245 customers. The reliability and validity tests were conducted. The collected data were analyzed using the SEM AMOS method.

Findings: The research results showed that: 1) e-service quality had a positive and significant influence on customer loyalty; 2) trust had a positive and significant influence on customer loyalty; 3) brand image had a positive and significant influence on customer satisfaction; 4) e-service quality had a positive and significant influence on customer loyalty; 5) customer trust had a positive and significant influence on customer loyalty; 6) brand image had a positive and significant influence on customer loyalty; 7) customer satisfaction had a positive and significant influence on customer loyalty; 8) e-service quality had a direct influence on customer loyalty without customer satisfaction as a mediator; 9) trust had a direct influence on customer loyalty without customer satisfaction as a mediator; 10) brand image had a direct influence on customer loyalty without customer satisfaction as a mediator.

Research limitation/implications: The research sample was Shopee customers in the Special Region of Yogyakarta. There had not been an analysis of other factors that influence customer satisfaction and loyalty, such as social risk and time risk.

Practical implications: Future research should expand the research sample to Shopee customers outside of Yogyakarta Special Region. For further research, it is recommended to modify the proposed model so that the goodness of fit criteria obtained will be fulfilled by the good criteria.

Originality/value: In the context of customer satisfaction and loyalty, this research had offered an empirical research model on the relationship among e-service quality, trust, brand image, customer satisfaction and customer loyalty on Shopee customers outside of Yogyakarta Special Region. The use of satisfaction had mediating influence of e-service quality, trust, brand image on customer loyalty.

Keywords: e-service quality, trust, brand image, customer satisfaction, customer loyalty.

\section{Introduction}

Considering the growing trend of e-commerce, business people in Indonesia are currently required to act quickly to reach customers, one of which is the use of e-commerce. E-commerce is buying and selling various products, services and information electronically, which focuses on business 
transactions using the internet.

In Indonesia, competition in the e-commerce industry is still dominated by large companies, Shopee. In 2015, Shopee was first launched in Singapore. Shopee first started as a customerto-customer (C2C) marketplace but had shifted to a C2C and Business for Customer (B2C) hybrid model since launching Shopee Mall, an online store platform for the distribution of well-known brands. Brand is an important part in achieving business continuity for the business (Hidayanti, Nuryakin, \& Farida, 2018).

Generally, the literature shows that the greater the e-service quality, the greater the electronic customer satisfaction. Apart from that, it was found that e-service quality also improves electronics, and it was found that e-service quality also increases customers' e-trust in service providers.

Chou et al. (2015) said that, besides e-service, customers must also feel satisfied with a website; they are more willing to interact with the website's future and become loyal customers. Many studies prove that satisfaction can directly affect loyalty, as research conducted shows that e-satisfaction is one of the main factors that play a role in building e-loyalty in the online trading system.

Another factor that can play a role in building loyalty is trust in an online site. According to Giovanis \& Athanasopoulou (2014), trust is a foundation in initiating, forming, and maintaining relationships between online customers and sellers. Bhat et al. (2018) argued that trust is an important factor that unites partners and makes them comfortable to conduct business transactions. The higher the trust, the higher the loyalty (Aslam et al., 2019).

The relationship among e-service quality, satisfaction, trust, and loyalty has been significant, but the strength of the relationship among the three can vary. Looking at the facts makes researchers interested in seeing the relationship among e-service quality, trust, brand image, and loyalty. Thus, this research is entitled "The Influence of E-Service Quality, Trust, Brand Image on Shopee Customer Satisfaction and Loyalty."

\section{Literature Review}

\section{Electronic Service Quality (E-Service Quality)}

Service quality is defined as a global assessment or attitude relating to overall service excellence (Parasuraman et al., 2005). Nonetheless, the meaning and measurement of service quality are significantly different in the online context due to the unique nature of the interactions between customers and service providers (Ribbink et al., 2004).

E-service quality or also known as E-ServQual, is a new version of Service Quality (ServQual). E-ServQual was developed to evaluate a service provided on the internet network. E-Service Quality is defined as the extension of a site's ability to effectively and efficiently facilitate shopping, purchasing, and distribution activities (Chase et al., 2006). Based on Ho \& Lee (2007), there are dimensions of e-service quality measurement, namely:

Firstly, Information Quality, namely information for customers on the website, is the most important thing in service quality because this is what customers feel directly. Secondly, Security which means how its customers can trust the website. The good online services performed can make customers more trustworthy. Beside that, security also means how to maintain customers' privacy, including customer personal data that has been inputted on the website. When security is lacking, it will cause customer distrust and will reduce customer satisfaction. Thirdly, Website Functionality is very important because this is the mainstay of service quality electronically. Lack of good online customer electronic services will be confused and need to find information on the needed products/services. If the customer continues to experience confusion, the customer will stop and feel that what is being done is not effective and efficient. Fourthly, Customer Relationships can make the website a place for a social organization online to provide users and customers opportunities to share opinions and exchange information in the community. Fifthly, Responsiveness and Fulfillment dimension measures how to respond to what is needed by the customer, whether on time to respond to it or not. Answering customer inquiries quickly and efficiently is very important. Because customers choose to use online for time efficiency, accuracy in answering customer questions and complaints is very important to pay attention. 


\section{Trust}

According to Mayer (2010), defining trust is a person's willingness to be sensitive to others' actions based on the expectation that other people will take certain actions on those who believe in them without depending on their ability to supervise and control them. He also explained that people who are trusted have a willingness and sensitivity to others' expectations who believe that their actions play a very important role.

\section{Brand Image}

Kotler \& Armstrong (2012) stated that brand image is owned by someone in the form of a set of ideas, beliefs, and impressions of a brand. Therefore, brand image determines consumer attitudes and actions. Brand image is the perception of a brand which reflects the consumer's memory of its association with the brand (Lee et al., 2014).

\section{Loyalty}

Customer loyalty has an important role in a company. Maintaining it means improving financial performance and maintaining the viability of the company. This is the main reason for a company to attract and retain it. That customer loyalty tends to be closer to behavior, not attitude. Customer loyalty is the tendency of a customer to buy or use a product or service to convey and recommend to others the product or service that has been received. In the end, customers will be loyal to these products or services and reject similar products or services offered by different companies.

This study develops 10 (ten) hypotheses that show the relationship among the variables studied. Research conducted by Setiawan \& Sayuti (2017) showed an influence between service quality and customer satisfaction. This research was conducted on consumers who have used the services of tour and travel companies in South Sumatra. Research conducted by Nuseir (2010) showed that e-service quality positively and significantly affects satisfaction. This research was conducted on bank customers in Jordan. This research was about customer satisfaction is formed because bank customers are responsive, the website's attributes and their respective adjustments. Based on theory and supported by the research results of Setiawan \& Sayuti (2017), Gera (2011), and Nuseir (2010), it can be stated that e-service quality has a positive and significant influence on customer satisfaction.

H1: E-service quality has a positive and significant influence on customer satisfaction.

Rasyid \& Sugiyono (2014) revealed that trust has a positive and significant influence on loyalty. Trust arises when someone feels confident in a product and in the end, it will make someone loyal to the brand. Research conducted by Chou et al. (2015) had proven that online shopping satisfaction will influence trust in the company and its products. The greater the customer satisfaction, the greater the customer trust in the product or service purchased. Based on these researches, a hypothesis can be formulated:

H2: Trust has a significant and positive influence on satisfaction.

Research conducted by Shahroudi \& Naimi (2014) examined the influence of brand image on customer satisfaction in consumer hygiene products. Furthermore, the result is the brand image has a positive effect on customer satisfaction. Research conducted by Kariuki (2015) aimed to determine the impact of brand image on customer satisfaction in supermarkets in Kenya. The research population was 15 supermarkets operating in Nairobi. The results of this research indicated that brand image and customer satisfaction have a positive and significant relationship. Customer satisfaction is important in retaining customers. Research conducted by Upamannyu \& Sankpal (2014) aimed to determine the benefits of brand image on customer satisfaction at cosmetic brands (Fair Lovely) in Gwalior, India. The results showed that brand image influences customer satisfaction. Based on theory and supported by the research results of Shahroudi \& Naimi (2014), Kariuki (2015), and Upamannyu \& Sankpal (2014), it can be stated that brand image has a positive and significant effect on customer satisfaction. 
H3: Brand image has a positive and significant influence on customer satisfaction.

Research conducted by Asgari (2014) showed that there is an influence of e-service quality on e-loyalty. The purpose of this research was to determine the effect of e-service quality on bank customer e-loyalty. This research was conducted on Hekmat Bank customers in Iran. Research conducted by Cristobal et al. (2007) showed that perceived e-service quality can affect loyalty. This relevant research on perceived quality on the internet focuses on aspects of web design. The existing literature on internet consumer behavior has not fully analyzed the benefits generated by higher perceived quality in terms of user satisfaction and loyalty. A research conducted by Sundaram et al. (2017) stated that e-service quality significantly and positively influences customer loyalty. This research was conducted on e-commerce, aiming to test e-service quality with customer satisfaction and customer loyalty. E-service quality is important to build customer loyalty because now onlinebased businesses have started to develop a lot; thus, e-service quality can determine customer loyalty. Based on the theory and supported by the research results of Asgari (2014), Cristobal et al. (2007), and Sundaram et al. (2017), it can be stated that e-service quality has a positive and significant influence on customer loyalty.

H4: E-service quality has a positive and significant influence on customer loyalty.

Rasyid and Sugiyono (2014) revealed that trust has a positive and significant influence on loyalty. Trust arises when someone feels confident in a product, and in the end, it will make someone loyal to the brand. Another research conducted by Chou et al. (2015) entitled "Female Online Shoppers: Examining the Mediating Roles of E-satisfaction and E-trust on E-loyalty Development" showed that e-trust also has a positive effect on e-loyalty and becomes a mediator. In the context of electronic business, Kim et al. (2009) conducted a research to propose and test an integrative model of the e-loyalty development process. The results showed that in the process of developing e-loyalty, e-trust is one of the factors that influence it. Kassim \& Abdullah (2012) also researched the context of e-commerce and showed the results that trust has a significant influence on customer loyalty through word of mouth (WOM).

H5: Trust has a positive and significant influence on Brand Loyalty.

Research conducted by Kumowal et al., (2016) stated that brand image positively influences customer loyalty. This research revealed that the store brand image and service quality in a store strongly influence customer satisfaction, trust, and commitment to become loyal customers. Research conducted by Onyancha (2013) aimed to determine the relationship among the bank's brand image, customer satisfaction, and customer loyalty to the Kenya Commercial Bank (K.C.B.). This research indicated that the brand image of the bank has a positive effect on customer loyalty. Research conducted by Sönmez (2014) aimed to determine the relationship between brand image and customer loyalty in banks located in Ankara and Istanbul, Turkey. The results showed that brand image influences customer loyalty. Brand image is very important in the banking sector. Research conducted by Sulibhavi \& Shivashankar (2017) aimed to determine the relationship among brand image, satisfaction, and customer loyalty to private label brands in Hubli-Dharwad. This research was conducted by distributing 186 valid questionnaires and showing a significant relationship between brand image and customer loyalty. Based on theory and supported by research results by Kumowal et al., (2016), Kumowal et al., (2016), Sonmez (2014), and Sulibhavi \& Shivashankar (2017), it can be stated that brand image has a positive and significant influence on customer loyalty. H6: Brand image has a positive and significant influence on customer loyalty.

Research conducted by Srivastava (2015) showed a positive relationship between customer satisfaction and customer loyalty. This research aimed to develop a holistic research framework to investigate the dynamic relationship between two business success metrics - customer satisfaction and customer loyalty. Research conducted by Nayebzadeh et al., (2013) aimed to examine the relationship between customer satisfaction and customer loyalty with bank financial performance 
through field studies. These research' results indicated a strong positive relationship between customer satisfaction and customer loyalty by $95 \%$. One of the variables of customer satisfaction and customer loyalty is significantly related to the bank's performance by $90 \%$. Based on theory and supported by the research results of Srivastava (2015), Nayebzadeh et al., (2013), and Ibojo (2015), it can be stated that customer satisfaction has a positive and significant influence on customer loyalty.

H7: Customer satisfaction has a positive and significant influence on customer loyalty.

Research conducted by Laurent (2016) showed that e-service quality positively influences customer loyalty through customer satisfaction. This research aimed to determine the influence of eservice quality on GO-jek customer loyalty through customer satisfaction. Research conducted by Santouridis \& Trivellas (2010) aimed to determine the important factors that lead to customer loyalty in Greece's cellular telephone sector, namely service quality and customer satisfaction. Furthermore, the research also found a mediating effect of customer satisfaction on service quality and customer loyalty relationships. In this research, customer satisfaction's mediating role on service quality has a positive and significant effect on customer loyalty. Based on the theory and supported by the research results of Laurent (2016) and Santouridis \& Trivellas (2010), it can be stated that customer satisfaction plays a role as a mediator of the influence of e-service quality on customer loyalty.

H8: Customer satisfaction acts as a mediator of the influence of e-service quality on customer loyalty.

Research results from Deng et al., (2010) stated that trust influences loyalty through customer satisfaction. If the company can pay attention for the customer's trust, the customer will be satisfied to lead customer loyalty on the brand.

H9: Customer satisfaction acts as a mediator of the influence of trust on customer loyalty.

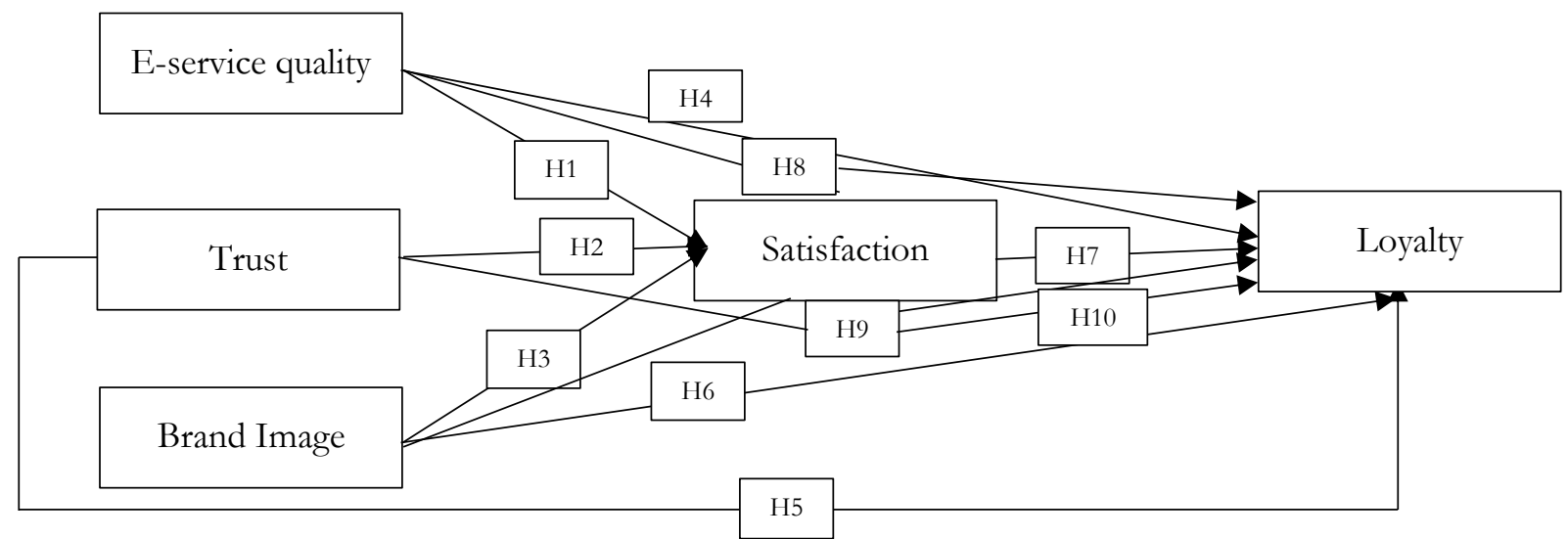

Sources: Setiawan (2017), Sulibhavi \& Shivashankar (2017), Shahroudi \& Naimi (2014), Laurent (2016), Saputra (2013)

Figure 1. Research Model

This research was conducted by Saputra (2013) which stated that company image has a positive and significant influence on the decision to provide good customer satisfaction with the support of service quality. Pramudyo (2012) conducted this research showing that customer satisfaction is an intervening variable that positively influences brand image and loyalty. These results indicated that students become loyal to the existence of a positive brand image and higher education. Based on the theory and supported by the research results of Saputra (2013) and Pramudyo (2012), it can be stated that customer satisfaction plays a role as a mediator for the influence of brand image on customer loyalty.

H10: Customer satisfaction acts as a mediator of the influence of brand image on customer loyalty.

\section{Methods}

In this research, the research population was the Shopee website/application in the Yogyakarta Special Region. In the sampling technique, the researcher used the purposive sampling technique 
where this research was not conducted on the entire population but focused on the target. According to Sekaran \& Bougie (2013), purposive sampling means a sampling technique with certain considerations. The sample characteristics used in the research were (1) Customers who had made purchase transactions on the Shopee website/application at least three times (2) Customers who were currently domiciled in the Special Region of Yogyakarta, and (3) customers aged from 17 up to 65 years.

The sample determination size has a role in interpreting the results of structural equational modeling (SEM). The most common SEM estimation procedure is the maximum likelihood (ML). Of the questionnaires that were distributed, 250 questionnaires were returned to be followed up. After further investigation through the verification process, of the 250 questionnaires returned, only 243 questionnaires were completed and fulfilled the further analysis requirements. After the outlier analysis was carried out, no outliers were found. Thus, all 243 respondent data could be used in further analysis.

The sample size's adequacy that must be met in this modeling was a minimum of 100-200 samples or the number of estimated parameters multiplied by 5-10 (Sekaran \& Bougie (2010). Respondents were analyzed according to respondents' characteristics: gender, age, occupation, and income. These aspects were important respondent characteristics that can be linked to research variables. Respondent characteristics were analyzed using descriptive statistics with SPSS program, namely: cross-tabulation (crosstab), frequency distribution, and index value analysis. Descriptive statistics is a method related to collecting and presenting data to provide useful information (Sholiha \& Salamah, 2015).

The research hypothesis testing was carried out using the Structural Equation Modeling (SEM) approach using AMOS version 22. Structural Equation Modeling (SEM) collects statistical techniques that allow testing a series of relatively complex relationships simultaneously. Thus, the researcher used this analysis tool because of the existence of several complex relationships of several variables tested in this research. The Structural Equation Modeling (SEM) approach using AMOS can combine several techniques, including factor analysis, path analysis, and regression analysis. Therefore according to Ghozali (2017), to test the hypothesis, the Cronbach Ratio value (C.R) is $\geq 1.967$ or the significant probability value (p) is $\leq 0.05$ (significant at $5 \%$ rate).

Related to the characteristics of respondents in this research, most of Shopee customer were dominated by women aged 17-25 years of $50.2 \%$, students of $36.2 \%$ with a shopping frequency $>6$ of $70.8 \%$ and income per month $1.5-2$ million of $51.4 \%$.

Table 1. Standardized Regression Weight CFA Test

\begin{tabular}{lcccccc}
\hline \multicolumn{1}{c}{ Indicator } & $\begin{array}{c}\text { Loading } \\
\text { Factor }\end{array}$ & Information & & Indicator & $\begin{array}{c}\text { Loading } \\
\text { Factor }\end{array}$ & Information \\
\hline SQ1 & 0.934 & Valid & & SQ20 & 0.834 & Valid \\
SQ2 & 0.917 & Valid & & K1 & 0.931 & Valid \\
SQ3 & 0.940 & Valid & & K2 & 0.945 & Valid \\
SQ4 & 0.926 & Valid & & K3 & 0.949 & Valid \\
SQ5 & 0.885 & Valid & & K4 & 0.964 & Valid \\
SQ6 & 0.928 & Valid & & CM1 & 0.907 & Valid \\
SQ7 & 0.891 & Valid & & CM2 & 0.951 & Valid \\
SQ8 & 0.879 & Valid & & CM3 & 0.966 & Valid \\
SQ9 & 0.888 & Valid & & CM4 & 0.918 & Valid \\
SQ10 & 0.864 & Valid & & K1 & 0.931 & Valid \\
SQ11 & 0.887 & Valid & & K2 & 0.945 & Valid \\
SQ12 & 0.824 & Valid & & K3 & 0.949 & Valid \\
SQ13 & 0.904 & Valid & & K4 & 0.964 & Valid \\
SQ14 & 0.867 & Valid & & K5 & 0.898 & Valid \\
SQ15 & 0.879 & Valid & & L1 & 0.940 & Valid \\
SQ16 & 0.900 & Valid & & L2 & 0.985 & Valid \\
SQ17 & 0.876 & Valid & & L3 & 0.998 & Valid \\
SQ18 & 0.883 & Valid & L4 & 0.949 & Valid \\
SQ19 & 0.879 & Valid & & & & \\
\hline
\end{tabular}


The data analysis method was carried out in the assistance of IBM Statistics AMOS version 24. The validity test was based on Ghozali (2017) with confirmatory factor analysis (CFA). CFA analysis is used to test the concept building using several measurable indicators. The loading factor can be used to measure construct validity. Thus, the questionnaire can be said to be valid if the question can reveal something measured by a questionnaire. The validity of the construction can be known by looking at the standard factor value loading of each indicator. If the standard loading factor value is $\geq 0.5$ or ideally 0.7 , it can be declared valid (Ghozali, 2017). Meanwhile, if the value is invalid, the indicator must be dropped in the next analysis.

The reliability of a measuring instrument can be seen from the resulting CR (Construct Reliability) and AVE (Average Variance Extracted) values. If the CR value is obtained from the calculation of $\geq 0.70$ and the AVE value from the calculation $\geq$ of 0.50 , the variable's measuring instrument is declared reliable (Ghozali, 2017). The following are the results of the calculation of the reliability test on each variable:

Table 2. Reliability Test Results

\begin{tabular}{|c|c|c|c|}
\hline Variable & Indicator & CR & AVE \\
\hline E-service quality & $\begin{array}{l}\text { SQ1 } \\
\text { SQ2 } \\
\text { SQ3 } \\
\text { SQ4 } \\
\text { SQ5 } \\
\text { SQ6 } \\
\text { SQ7 } \\
\text { SQ8 } \\
\text { SQ9 } \\
\text { SQ10 } \\
\text { SQ11 } \\
\text { SQ12 } \\
\text { SQ13 } \\
\text { SQ14 } \\
\text { SQ15 } \\
\text { SQ16 } \\
\text { SQ17 } \\
\text { SQ18 } \\
\text { SQ19 } \\
\text { SQ20 }\end{array}$ & 0.987 & 0.796 \\
\hline Trust & $\begin{array}{l}\text { P1 } \\
\text { P2 } \\
\text { P3 } \\
\text { P4 }\end{array}$ & 0.984 & 0.937 \\
\hline Brand image & $\begin{array}{l}\text { CM1 } \\
\text { CM2 } \\
\text { CM3 } \\
\text { CM4 }\end{array}$ & 0.965 & 0.875 \\
\hline Customer satisfaction & $\begin{array}{l}\text { K1 } \\
\text { K2 } \\
\text { K3 } \\
\text { K4 } \\
\text { K5 }\end{array}$ & 0.973 & 0.879 \\
\hline Customer Loyalty & $\begin{array}{l}\text { L1 } \\
\text { L2 } \\
\text { L3 } \\
\text { L4 }\end{array}$ & 0.984 & 0.938 \\
\hline
\end{tabular}

From Table 2, the $C R$ value of all research variables had the value of $\geq 0.70$ and the overall AVE value had a value of 0.50 . Thus, based on these results, the researcher concluded that the 
measuring instruments used in all research variables had met the criteria and were reliable. The customer loyalty variable showed the highest reliable value, meaning that the respondents' answers to the loyalty variable indicators had the highest level of trust compared to other variables.

Table 3. Hypothesis Test Results of Regression Weighs

\begin{tabular}{|c|c|c|c|c|c|c|c|}
\hline & & & Estimation & S.E. & C.R. & $\mathbf{P}$ & Description \\
\hline E-service quality & $\rightarrow$ & Satisfaction & 0.624 & 0.066 & 9.417 & 0.000 & $\begin{array}{c}\mathrm{H} 1 \\
\text { Received }\end{array}$ \\
\hline Trust & $\rightarrow$ & Satisfaction & 0.107 & 0.037 & 2.856 & 0.004 & $\begin{array}{c}\mathrm{H} 2 \\
\text { Received }\end{array}$ \\
\hline Brand Image & $\rightarrow$ & Satisfaction & 0.210 & 0.048 & 4.357 & 0.000 & $\begin{array}{c}\mathrm{H} 3 \\
\text { Received }\end{array}$ \\
\hline E-service quality & $\rightarrow$ & Loyalty & 0.491 & 0.076 & 6.434 & 0.000 & $\begin{array}{c}\mathrm{H} 4 \\
\text { Received }\end{array}$ \\
\hline Trust & $\rightarrow$ & Loyalty & 0.115 & 0.037 & 3.096 & 0.002 & $\begin{array}{c}\text { H5 } \\
\text { Received }\end{array}$ \\
\hline Brand Image & $\rightarrow$ & Loyalty & 0.116 & 0.049 & 2.376 & 0.018 & $\begin{array}{c}\text { H6 } \\
\text { Received }\end{array}$ \\
\hline Satisfaction & $\rightarrow$ & Loyalty & 0.374 & 0.070 & 5.327 & 0.000 & $\begin{array}{c}\mathrm{H} 7 \\
\text { Received }\end{array}$ \\
\hline
\end{tabular}

From the test results using SEM, the model estimation results of P-value will be compared with the critical value of 0.05 . The C.R. value of the model estimation results will be compared with the critical value of 1.96. If the P-value is below 0.001, the independent (exogenous) variable is declared to influence the dependent variable (endogenous), and the research hypothesis is accepted, whereas if the P-value exceeds 0.05, the independent (exogenous) variable is declared to have no significant effect on the independent (endogenous) variable and the hypothesis research is rejected. As for comparing critical values using C.R., the value of C.R., which exceeds 1.96, is declared that the independent variable (exogenous) has a significant effect on the dependent variable (endogenous) and the hypothesis is accepted. Whereas, if the value of C.R. is below 1.96, the independent variable is considered to have no significant influence on the dependent variable and the hypothesis is rejected.

Based on the researcher's research model where there was an intervening variable (mediation) of customer satisfaction which linked the e-service quality and customer loyalty variables, it did not have a significant effect. This was proven that the standardized direct effect value was 0.405. It was higher than the standardized indirect effect value of 0.192 . Thus, it can be concluded that the mediating effect of customer satisfaction did not have a significant influence on the relationship between e-service quality and customer loyalty.

The intervening variable (mediation) of customer satisfaction which linked the trust and customer loyalty variables, it did not have a significant effect. This was proven that the standardized direct effect value was 0.133 . It was higher than the standardized indirect effect value of 0.046 . Thus, it can be concluded that the mediating effect of customer satisfaction did not have a significant influence on the relationship between trust and customer loyalty.

The intervening variable (mediation) of customer satisfaction which linked the brand image and customer loyalty variable, it did not have a significant effect. This was proven that the standardized direct effect value was 0.108 . It was higher than the standardized indirect effect value of 0.073. Thus, it can be concluded that the mediating effect of customer satisfaction did not have a significant influence on the relationship between brand image and customer loyalty.

\section{Results and Discussion}

The results of the research determined the influence of e-service quality on Sophee customer satisfaction. It showed that C.R. value was 9.417 with the significance value of 0.000 because the significance was less than $0.05(\mathrm{p}<0.05)$ and the regression coefficient had a positive value. It also 
showed that e-service quality had a positive and significant influence on customer satisfaction. The higher the e-service quality, the higher the customer satisfaction.

The results of the research determined the influence of trust on Sophee customer satisfaction. It showed that C.R. value was 2.856 with the significance value of 0.004 because the significance was less than $0.05(\mathrm{p}<0.05)$ and the regression coefficient had a positive value. It also showed that trust had a positive and significant influence on customer satisfaction. The higher the trust, the higher the customer satisfaction.

The results of this research determined the influence of brand image on Sophee customer satisfaction. It showed that C.R. value was 4.357 with the significance value of 0.000 because the significance was less than $0.05(\mathrm{p}<0.05)$ and the regression coefficient had a positive value. It also showed that brand image had a positive and significant influence on customer satisfaction. The higher the brand image, the higher the customer satisfaction.

The results of the research determined the influence of e-service quality on Sophee customer loyalty. It showed that C.R. value was 6.434 with the significance value of 0.000 because the significance was less than $0.05(\mathrm{p}<0.05)$ and the regression coefficient had a positive value. It also showed that e-service quality had a positive and significant influence on customer loyalty. The higher the e-service quality, the higher the customer loyalty.

The results of the research determined the influence of trust on Sophee customer loyalty. It showed that C.R. value was 3.096 with the significance value of 0.002 because the significance was less than $0.05(\mathrm{p}<0.05)$ and the regression coefficient had a positive value. It also showed that trust had a positive and significant influence on customer loyalty. The higher the trust, the higher the customer loyalty.

The results of the research determined the influence of brand image on Sophee customer loyalty. It showed that the value of C.R. was 2.376 with the significance value of 0.018 because the significance was less than $0.05(\mathrm{p}<0.05)$ and the regression coefficient had a positive value. It also showed that brand image had a positive and significant influence on customer loyalty. The higher the brand image, the higher the customer loyalty.

The results of the research determined the influence of customer satisfaction on Sophee customer loyalty. It showed that the value of C.R. was 5.327 with the significance value of 0.000 because the significance was less than $0.05(\mathrm{p}<0.05)$ and the regression coefficient had a positive value. It also showed that customer satisfaction had a positive and significant influence on customer loyalty. The higher the customer satisfaction, the higher the customer loyalty.

The mediation test of customer satisfaction on the relationship between e-service quality and customer loyalty showed that the standardized direct effect value was 0.405 , which was higher than the standardized indirect effect value of 0.192 . These results indicated that high service quality will directly affect customer loyalty without having to go through satisfaction. It is possible that consumer satisfaction was not only measured from convenience, product information, financial security, attractive website appearance but needed to be supported by non-electronic services, where these services could not be read on the website but directly felt by consumers.

The mediation test of customer satisfaction on the relationship between trust and customer loyalty showed that the standardized direct effect value was 0.13 , which was higher than the standardized indirect effect value of 0.046 . From the results shown in the mediation test above, customer satisfaction could not provide a significant influence between customer trust and loyalty. According to researchers, although customer satisfaction affected customer loyalty, customers had another perception that it was more supportive of trust in customer loyalty. In this case, the perception of trust as a whole had a greater effect on customer loyalty than just seeing the perception of customer satisfaction.

The results of the mediation test of customer satisfaction on the relationship between brand image and customer loyalty showed that the standardized direct effect value was 0.018 , higher than the standardized indirect effect value of 0.073 .

From the results shown in the mediation test above, customer satisfaction cannot provide a significant influence between brand image and customer loyalty. According to researchers, although customer satisfaction affected customer loyalty, customers had other perceptions that were 
more supportive on brand image to customer loyalty. In this case, the perception of the brand image had a greater influence on customer loyalty than just seeing the perception of customer satisfaction.

\section{Conclusion}

This research indicated that (1) E-service quality had a significant and positive influence on customer satisfaction. The better the e-service quality, the higher the customer satisfaction. (2) Trust had a significant and positive influence on customer satisfaction. The better the trust, the higher the customer satisfaction. (3) Brand image had a significant and positive influence on customer satisfaction. The better the brand image, the higher the customer satisfaction. (4) E-service quality had a significant and positive influence on customer loyalty. The better the e-service quality, the higher the customer loyalty. (5) Trust had a significant and positive influence on customer loyalty. The better the trust, the higher the customer loyalty. (6) Brand image had a significant and positive influence on customer loyalty. The better the brand image, the higher the customer loyalty. (7) Customer satisfaction had a significant and positive effect on customer loyalty. The higher the customer satisfaction, the higher the customer loyalty. (8) E-service quality had a direct influence on customer loyalty without going through customer satisfaction. (9) Trust had a direct influence on customer loyalty without going through customer satisfaction. (10) Brand image had a direct influence on customer loyalty without going through customer satisfaction.

Future research should expand the research sample to Shopee customers outside of Yogyakarta Special Region. For further research, it is recommended to modify the proposed model so that the goodness of fit criteria will be fulfilled with the good criteria.

\section{References}

Ahmad, A., Rahman, O., \& Khan, M. N. (2017). Exploring the role of website quality and hedonism in the formation of e-satisfaction and e-loyalty. Journal of Research in Interactive Marketing, 11(3), 246-267.

Asgari, N., Ahmadi, M. H., Shamlou, M., Farokhi, A. R., \& Farzin, M. (2014). Studying the impact of E-service quality on E-loyalty of customers in the area of E-banking services. J. Mgmt. \& Sustainability, 4(2), 126.

Aslam, W., Tariq, A., \& Arif, I. (2019). The effect of ATM service quality on customer satisfaction and customer loyalty: An empirical analysis. Global Business Review, 20(5), 1155-1178.

Bhat, S. A., Darzi, M. A., \& Parrey, S. H. (2018). Antecedents of customer loyalty in banking sector: a mediational study. Vikalpa, 43(2), 92-105.

Chase, R., Jacobs, R., \& Aquilano, N. (2006). Operations Management-For Competitive Advantage, Eleventh E. McGrawn-Hill Irwin.

Chou, S., Chen, C.-W., \& Lin, J.-Y., (2015). Female online shoppers: Examining the mediating roles of e-satisfaction and e-trust on e-loyalty development. Internet Research, 25, 542-561.

Deng, Z., Lu, Y., Wei, K. K., \& Zhang, J. (2010). Understanding customer satisfaction and loyalty: An empirical study of mobile instant messages in China. International journal of information management, 30(4), 289-300.

Cristobal, E., Flavian, C., \& Guinaliu, M. (2007). Perceived e-service quality (PeSQ): Measurement validation and effects on consumer satisfaction and web site loyalty, Managing Service Quality: An International Journal, 17(3), 317-340.

Ghozali, I. (2017). Model persamaan struktural: Konsep dan aplikasi dengan program amos 24 edisi 7. Semarang: Universitas Diponegoro. 
Giovanis, A. N., \& Athanasopoulou, P. (2014). Gaining customer loyalty in the e-tailing marketplace: the role of e-service quality, e-satisfaction and e-trust. International Journal of Technology Marketing 6, 9(3), 288-304.

Hidayanti, I., Nuryakin, \& Farida, N. (2018). A study on brand commitment and brand trust towards brand loyalty of branded laptop in Indonesia. Journal of Business and Retail Management Research (JBRMR), Vol 12(2), pg. 270 - 278.

Ho, C. I. \& Lee, Y. L. (2007). The development of an e-travel service quality scale. Tourism Management, Journal of Management and Sustainability; 28(6), 1434- 1449.

Ibojo, B. O. (2015). Impact of customer satisfaction on customer retention: A case study of a reputable bank in Oyo, Oyo State, Nigeria. International Journal of Managerial Studies and Research (IJMSR), 3(2), 42-53.

Kariuki, M. N. (2015). The Impact of Brand Imageon Customer Satisfaction in Major Supermarkets in Nairobi Country. a research project presented in partial fulfilment of the requirements for the award of the degree of master of business administration (mba), school of business, University of Nairobi.

Kassim, N., \& Abdullah, N. A. (2010). The effect of perceived service quality dimensions on customer satisfaction, trust, and loyalty in e-commerce settings. Asia pacific journal of marketing and logistics, 22(3), 351-371.

Kim, J.H. \& Lennon, S.J. (2017), Descriptive content analysis on e-service research, International Journal of Service Science, Management, Engineering, and Technology, 8(1), 18-31.

Kotler, P., \& Amstrong. (2012). Principle of Marketing 14th Edition. New Jersey: Pearson Education,Inc.

Kumowal, R. C., Lapian, S. J., \& Tumiwa, J. (2016). The Effect of Store Brand Image and Service Quality Towards Customer Loyalty at Freshmart Superstore Manado. Jurnal EMBA: Jurnal Riset Ekonomi, Manajemen, Bisnis dan Akuntansi, 4(1), 306-314.

Laurent, F. (2016). Pengaruh e-service quality terhadap loyalitas pelanggan Go-jek melalui kepuasan pelanggan. Agora, 4(2), 95-100.

Lee, J. L., James, J. D., \& Kim, Y. K. (2014). A reconceptualization of brand image. International Journal of Business Administration, 5(4), 1-11.

Mayer, Richard E., (2010) Multimedia Learning, Yogyakarta: Pustaka Pelajar.

Nayebzadeh, S., Jalaly, M., \& Shamsi, H. M. (2013). The Relationship between Customer Satisfaction and Loyalty with the Bank Performance in IRAN. International Journal of Academic Research in Business and Social Sciences, 3(6), 114.

Nuseir, M. T., Akroush, M. N., Mahadin, B. K., \& Bataineh, A. Q. (2010). The effect of e-service quality on customers' satisfaction in banks operating in Jordan: an empirical investigation of customers' perspectives. International Journal of Services, Economics and Management, 2(1), 80108.

Onyancha, G. K. (2013). The impact of bank brand image on customer satisfaction and loyalty: A case of Kenya commercial bank. European Journal of Business and Management, 5(21), 35-39.

Parasuraman, A., Zeithaml, V. \& Malhotra, A. (2005). E-S-QUAL: a multiple-item scale for assessing electronic service quality, Journal of Service Research,7(3), 213-233.

Pramudyo, Anung. (2012). Pengaruh Citra Merk Terhadap Loyalitas Melalui Kepuasan Sebagai Intervening (Studi pada Mahasiswa Perguruan Tinggi Swasta di Yogyakarta). Jurnal JBMA, $1(1)$.

Gera, R. (2011). Effects of online service quality dimensions on satisfaction, value and behavioral outcomes. International Journal of Arts \& Sciences, 4(12), 123. 
Rasyid, Rafsanjani Harun Al \& Sugiyono. (2014). Pengaruh Kepuasan Konsumen, Kepercayaan dan Layanan Terhadap Loyalitas Berbelanja pada Carrefour Surabaya. Jurnal Ilmu dan Riset Manajemen, 3(12), 40-53.

Ribbink, D., Riel, A. C., Liljander, V., \& Streukens, S. (2004). Comfort your online customer: quality, trust and loyalty on the internet. Managing Service Quality, 14 (6), 446-456.

Santouridis, I., \& Trivellas, P. (2010). Investigating the impact of service quality and customer satisfaction on customer loyalty in mobile telephony in Greece. The TQM Journal. 22 (3), 330343.

Saputra, F. I. (2013). Kualitas Layanan, citra dan pengaruhnya terhadap loyalitas melalui kepuasan pelanggan (studi pada PT Bank Bni 46 sentra kredit kecil Surabaya). Jurnal aplikasi manajemen, 11(3), 445-457.

Setiawan, Heri and Sayuti A Jalaluddin., (2014). Effects of Service Quality, Customer Trust and Corporate Image on Customer Satisfaction and Loyalty: An Assessment of Travel Agencies Customer in South Sumatra Indonesia. IOSR Journal of Business and Management (IOSR-JBM), 19(5), 31-40.

Sekaran \& Bougie. (2013). Research Methods for Business: A skill Building Approach. 5 ed, New York: Johnwiley@Sons.

Shahroudi \& Naimi., (2014). The impact of brand image on customer satisfaction and loyalty intention (Case study: consumer of hygiene products). International journal of engineering innovation \& research, 3(1), 2277-5668.

Sholihah, Eva \& Salamah, Mutiah. (2015). Structural Equation Modeling-Partial Least Square untuk Pemodelan Derajat Kesehatan Kabupaten/Kota di Jawa Timur (Studi Kasus Data Indeks Pembangunan Kesehatan Masyarakat Jawa Timur 2013). Jurnal SAINS dan Seni ITS, 4(2), 169-174.

Sönmez, E. E. (2014). The Effect of Brand Image in Creating Customer Loyalty in Retail Banking: The Case of Yapi Kredi Bank in Turkey. Research Assistant.

Srivastava, M. (2015). Influencers of Customer Satisfaction, Customer Loyalty Relationship A Conceptual Research Model. Journal of Faculty of Management Studies, Banaras Hindu University, 7(1), 54-65.

Sulibhavi, B., \& Shivashankar, K. (2017). The Impact of Brand Image on Customer's Loyalty Towards Private Label Brands: The Mediating Effect of Satisfaction. Hubli Dharwad Conglomerate City of Karnataka. International Journal of Marketing \& Financial Management, 5(8), 43-50.

Sundaram, V., Ramkumar, D., \& Shankar, P. (2017). Impact of e-service quality on customer satisfaction and loyalty empirical study in India online business. Journal of Business and Management, 21(1), 4869.

Upamannyu, N. K., \& Sankpal, S., (2014). Effect of Brand Image on Customer Satisfaction \& Loyalty Intention, and The Role of Customer Satisfaction Between Brand Image and Loyalty Intention. Journal of the Academy of Marketing Science, 30(4), 286-295. 